\author{
Morten Hylander Møller \\ Maurizio Cecconi
}

\section{Venous-to-arterial carbon dioxide difference: an experimental model or a bedside clinical tool?}

Received: 24 November 2015

Accepted: 6 December 2015

Published online: 17 December 2015

(C) Springer-Verlag Berlin Heidelberg and ESICM 2015

M. H. Møller (®)

Department of Intensive Care 4131, Copenhagen University Hospital, Rigshospitalet, Blegdamsvej 9, 2100 Copenhagen, Denmark

e-mail: mortenhylander@gmail.com

Tel.: +45 22555343

M. Cecconi

Department of Anaesthesia and Intensive Care Medicine, St George's University of London, London, UK

In the present issue of Intensive Care Medicine, OspinaTascón et al. present an intriguing observational study in which they assessed the association between venous-toarterial carbon dioxide difference $\left(\mathrm{Pv}-\mathrm{aCO}_{2}\right)$ and microvascular perfusion in patients with early septic shock [1]. A total of 75 adult patients with septic shock from a 60-bed mixed ICU in Columbia were included in the study. Potentially eligible patients with septic shock in the ICU were screened, and those eligible had a pulmonary artery catheter (PAC) inserted and were included in the study. Arterial and mixed venous blood samples were collected at the insertion of the PAC (T0) and at $6 \mathrm{~h}$ (T6), and $\mathrm{Pv}-\mathrm{aCO}_{2}$ was defined as the difference between mixed-venous and arterial $\mathrm{CO}_{2}$ partial pressures. A sidestream dark-field imaging device was used to evaluate the microcirculation of the tongue at $\mathrm{T} 0$ and $\mathrm{T} 6$, and the association between $\mathrm{Pv}-\mathrm{aCO}_{2}$ and the microcirculation of the tongue was assessed. Furthermore, the association between $\mathrm{Pv}-\mathrm{aCO}_{2}$ and global haemodynamic variables was evaluated. The authors conclude that $\mathrm{Pv}^{-} \mathrm{aCO}_{2}$ was closely related to microcirculatory blood flow parameters during the early phase of septic shock, whereas $\mathrm{Pv}^{-\mathrm{aCO}_{2}}$ was poorly related to systemic haemodynamic variables [1].

Septic shock is a serious and frequent condition in the ICU, and early recognition and adequate treatment of tissue hypoperfusion is crucial [2, 3]. Oxygen-derived parameters such as central venous oxygen saturation $\left(\mathrm{ScVO}_{2}\right)$ have failed to demonstrate clinical benefit as resuscitation targets in recent large randomised controlled trials and systematic reviews [4-6]. Mean baseline $\mathrm{ScVO}_{2}$ was above $70 \%$ in all the trials, which may be explained by early recognition and aggressive treatment of shock. Nevertheless, while a low $\mathrm{ScVO}_{2}$ can prompt further resuscitation [3], in the context of normal or high $\mathrm{ScVO}_{2}$ its role is more questionable. Indeed, one of the limitations of using $\mathrm{ScVO}_{2}$ as a marker of hypoperfusion is that normal to high values cannot discriminate whether oxygen delivery is adequate or in excess of demand. High $\mathrm{ScVO}_{2}$ in the context of high lactate has for instance been shown to be associated with poor survival rates [7]. In this situation other tissue perfusion variables such as $\mathrm{Pv}_{\mathrm{aCO}}$ have been proposed $[8,9]$. In normal circumstances the difference between the arterial and the venous carbon dioxide is less than $6 \mathrm{mmHg}$. However, in states of low perfusion this difference can increase. In areas of the microcirculation that are poorly perfused there is an increased local production of $\mathrm{CO}_{2}$. Despite poor perfusion, since $\mathrm{CO}_{2}$ is about 20 times more soluble than $\mathrm{O}_{2}$, the likelihood of $\mathrm{CO}_{2}$ diffusing out of ischemic tissues and into the venous effluent is high, making it a very sensitive marker of hypoperfusion. Vallée et al. demonstrated that in septic patients with normalized $\mathrm{ScVO}_{2}$, high central venous-to-arterial $\mathrm{CO}_{2}$ difference (Pcv$\mathrm{aCO}_{2}$ ) was associated with worse outcomes in terms of lower lactate clearance, lower cardiac index, and higher sepsis-related organ failure assessment (SOFA) score [8]. Ospina-Tascón et al.'s study adds to the evidence that 
Fig. 1 Algorithm for the assessment of patients with shock

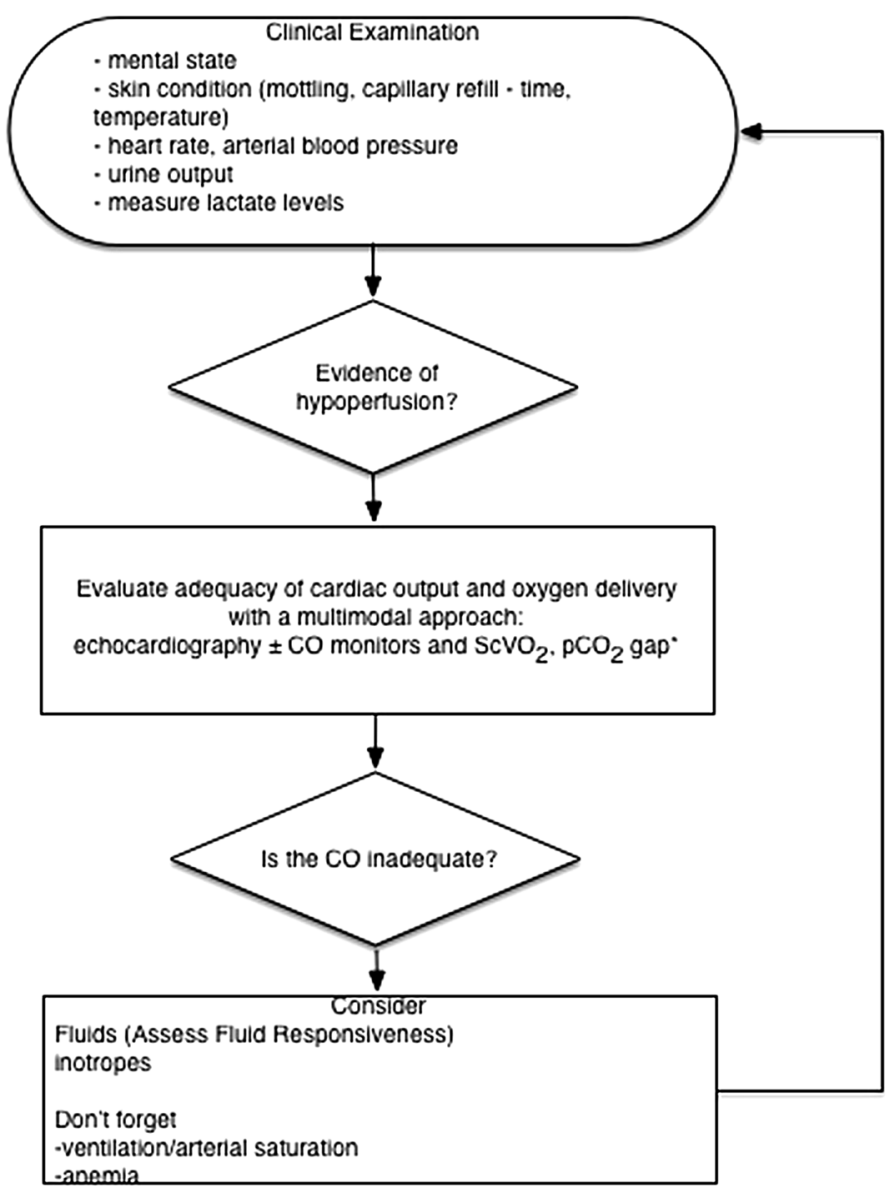

if ScVO2 > 70\% assess pCO2 gap. A pCO2 gap> $0.8 \mathrm{kpa}$ or $6 \mathrm{mmHg}$ suggests that inadequacy of cardiac output is still present
$\mathrm{P}(\mathrm{c}) \mathrm{V}-\mathrm{aCO} \mathrm{CO}_{2}$ may be a useful tool to identify patients who remain inadequately resuscitated when an $\mathrm{ScVO}_{2}$ of $70 \%$ has been reached [10]. Consequently, $\mathrm{Pv}-\mathrm{aCO}_{2}$ may prove useful in the assessment of patients with shock (Fig. 1).

While there seems to be convincing evidence that $\mathrm{P}(\mathrm{c}) \mathrm{v}-\mathrm{aCO}_{2}$ is a marker of (microcirculatory) hypoperfusion, a number of unanswered questions and limitations regarding routine clinical bedside use of $\mathrm{Pv}_{-} \mathrm{aCO}_{2}$ exist. First, use of $\mathrm{Pv}_{-} \mathrm{aCO}_{2}$ has not been tested in (randomised) clinical trials. Consequently, there is a risk of falsely inflated estimates [11], and the balance between benefits and harms are unknown. Second, there is a lack of Pv$\mathrm{aCO}_{2}$ studies assessing patient-important outcome measures with adequate follow-up [12]. Trials using nonpatient-important outcome measures (surrogate outcomes) overestimate the intervention effect by $40-50 \%$ [13]. Third, existing studies have mainly been conducted in small single-centre institutions, which increases the risk of reporting falsely inflated estimates [14, 15]. Finally, the unblinded assessment of the association between $\mathrm{Pv}-\mathrm{aCO}_{2}$ and the microcirculation increases the risk of selection bias [15].

In conclusion, $\mathrm{Pv}_{-} \mathrm{aCO}_{2}$ is an interesting and potentially important new tool for evaluation of the microcirculation in critically ill patients with shock; however, additional clinical evaluation, including adequate assessment of benefits and harms in high-quality randomised clinical trials, is needed prior to routine clinical use at the bedside.

\section{Compliance with ethical standards}

Conflicts of interest None. 


\section{References}

1. Ospina-Tascón GA, Umaña M, Bermúdez WF, Bautista-Rincón DF, Valencia JD, Madriñán HJ, Hernandez G, Bruhn A, Arango-Dávila C, De Backer D (2015) Can venous-to-arterial carbon dioxide differences reflect microcirculatory alterations in patients with septic shock? Intensive Care Med. doi:10.1007/s00134-015-4133-2 [Epub ahead of print]

2. Vincent JL, De Backer D (2013) Circulatory shock. N Engl J Med 369:1726-1734

3. Cecconi M, De Backer D, Antonelli M, Beale R, Bakker J, Hofer C, Jaeschke R Mebazaa A, Pinsky MR, Teboul JL, Vincent JL, Rhodes A (2014) Consensus on circulatory shock and hemodynamic monitoring. Task force of the European Society of Intensive Care Medicine. Intensive Care Med 40:1795-1815

4. Angus DC, Barnato AE, Bell D, Bellomo R, Chong CR, Coats TJ, Davies A, Delaney A, Harrison DA, Holdgate A, Howe B, Huang DT, Iwashyna T, Kellum JA, Peake SL, Pike F, Reade MC, Rowan KM, Singer M, Webb SA, Weissfeld LA, Yealy DM, Young JD (2015) A systematic review and meta-analysis of early goal-directed therapy for septic shock: the ARISE, ProCESS and ProMISe investigators. Intensive Care Med 41:1549-1560

5. Peake SL, Delaney A, Bailey M, Bellomo R, Cameron PA, Cooper DJ, Higgins AM, Holdgate A, Howe BD, Webb SA, Williams P (2014) Goaldirected resuscitation for patients with early septic shock. N Engl J Med 371:1496-1506
6. Mouncey PR, Osborn TM, Power GS, Harrison DA, Sadique MZ, Grieve RD, Jahan R, Harvey SE, Bell D, Bion JF, Coats TJ, Singer M, Young JD, Rowan KM, Pro MTI (2015) Trial of early, goal-directed resuscitation for septic shock. N Engl J Med 372:1301-1311

7. Puskarich MA, Trzeciak S, Shapiro NI, Arnold RC, Heffner AC, Kline JA, Jones AE, Emergency Medicine Shock Research Network (EMSHOCKNET) (2012) Prognostic value and agreement of achieving lactate clearance or central venous oxygen saturation goals during early sepsis resuscitation. Acad Emerg Med 19:252-258

8. Vallee F, Vallet B, Mathe O, Parraguette J, Mari A, Silva S, Samii K, Fourcade O, Genestal M (2008) Central venous-to-arterial carbon dioxide difference: an additional target for goaldirected therapy in septic shock? Intensive Care Med 34:2218-2225

9. van Beest PA, Lont MC, Holman ND, Loef B, Kuiper MA, Boerma EC (2013) Central venous-arterial $\mathrm{pCO}(2)$ difference as a tool in resuscitation of septic patients. Intensive Care Med 39:1034-1039

10. Vallet B, Pinsky MR, Cecconi M (2013) Resuscitation of patients with septic shock: please "mind the gap"! Intensive Care Med 39:1653-1655

11. Ziff OJ, Lane DA, Samra M, Griffith M, Kirchhof P, Lip GY, Steeds RP, Townend J, Kotecha D (2015) Safety and efficacy of digoxin: systematic review and meta-analysis of observational and controlled trial data. BMJ 351:h4451
12. Frank L, Basch E, Selby JV, PatientCentered Outcomes Research I (2014) The PCORI perspective on patientcentered outcomes research. JAMA 312:1513-1514

13. Ciani O, Buyse M, Garside R, Pavey T, Stein K, Sterne JA, Taylor RS (2013) Comparison of treatment effect sizes associated with surrogate and final patient relevant outcomes in randomised controlled trials: metaepidemiological study. BMJ 346:f457

14. Bafeta A, Dechartres A, Trinquart L, Yavchitz A, Boutron I, Ravaud P (2012) Impact of single centre status on estimates of intervention effects in trials with continuous outcomes: metaepidemiological study. BMJ 344:e813

15. Savovic J, Jones HE, Altman DG, Harris RJ, Juni P, Pildal J, Als-Nielsen B, Balk EM, Gluud C, Gluud LL, Ioannidis JP, Schulz KF, Beynon R, Welton NJ, Wood L, Moher D, Deeks JJ, Sterne JA (2012) Influence of reported study design characteristics on intervention effect estimates from randomized, controlled trials. Ann Intern Med 157:429-438 